E-Journal of Tourism Vol.8. No.2. (2021): 133-139

\title{
Agrotourism Development in Sukalarang Village, Sukabumi Regency
}

\author{
Agustina Eka Putri*, Reiza D. Dienaputra, Evi Novianti, Ute Lies Khadijah \\ Universitas Padjadjaran, Indonesia \\ *Corresponding Author: agustina19001@mail.unpad.ac.id \\ DOI: https://doi.org/10.24922/eot.v8i2.70975
}

\begin{abstract}
Article Info
Submitted:

March $2^{\text {nd }} 2021$.

Accepted:

September $24^{\text {th }} 2021$.

Published:

September $30^{\text {th }} 2021$
\end{abstract}

\begin{abstract}
The diversity of attractiveness of agricultural cultivation supported by a strategic location, unspoiled environment, mostly agricultural land, and community friendliness can be the main attraction for tourists and Sukalarang Village, Sukabumi Regency has it all. This study aims to identify the attractiveness of Sukalarang Village through agrotourism and analyze its development strategy. The qualitative method is this research approach with online primary and secondary data sources through previous research, online media, and government regulatory documents. Data collection techniques using online questionnaires and interviews. The research analysis used was qualitative and descriptive. This finding is expected to be able to answer the potential attraction of Sukalarang Village agro-tourism because the people in Sukalarang Village still make agricultural and plantation activities their daily activities and formulate development strategies as an agro-tourism village with the initiation of plantation owners and the village government. Sukalarang Village.
\end{abstract}

Keywords: Agrotourism, Sukabumi Regency, Sukalarang Village, Sustainable Tourism, Tourism Village

\section{INTRODUCTION}

Indonesia is one of the developing countries in the world which is currently increasing development in all fields ranging from the economy to agriculture. This can be seen from the number of regions that are centers of activity and population growth, one of which is service consumption areas in the form of agricultural tourism commodities. Consumption of services in the form of agricultural tourism commodities in Indonesia tends to experience a rapid increase. This increase can be seen from the number of tourist visits from both foreign countries who come to Indonesia, this is a sign of the high demand for agro- tourism and at the same time opens opportunities for the development of agricultural products in the form of areas or agricultural products that have specific appeal. (Departemen Pertanian, 2003). Agricultural commodities with their diversity and uniqueness have become a strong attraction for agrotourism. Herrera and Magdalena (2004) states that agrotourism is a series of rural activities, including participating in farming activities, learning local culture, enjoying the scenery and biodiversity, practicing organic and conventional farming, and harvesting tropical fruits and vegetables. Brščić (2006) also adds that agrotourism is a selective form of tourism that takes place in family farms and is a specific 
form of business with multiple impacts on socio-economic and spatial relations in rural areas. Furthermore, López and García (2006) states that agrotourism is a recreational activity that has been successful in the field of rural and cultural environments at attractive prices for various markets.

With the geographical position that is passed by the equator and its diverse natural, biological and cultural wealth, Indonesia has great potential to develop agrotourism, especially tourist villages. Nuryanti (1993) states that a tourism village is a form of integration between attractions, accommodation, and supporting facilities that are presented in a structure of community life that integrates with prevailing customs and traditions. One that has agrotourism potential is Sukalarang Village, Sukabumi Regency. One that has agrotourism potential is Sukalarang Village, Sukabumi Regency. The diversity of agricultural cultivation attractions supported by a strategic location, an unspoiled environment, largely agricultural land, and community friendliness can be an attractive attraction for tourists. The value of each measured parameter can then be combined to form a potential value of each tourist attraction so that it can be seen which attractions have low potential, medium potential, high potential, and very high potential.

\section{Research Objectives}

It is necessary to manage and develop agrotourism by analyzing the potential contained in tourism villages, both agriculture, and agrotourism to provide optimal benefits for the welfare of the local community. This study aims: 1) to identify the attractiveness of Sukalarang Village, and 2) to develop strategy of Agrotourism in Sukalarang Village.

\section{LITERATURE REVIEW}

\section{Agrotourism}

http://ojs.unud.ac.id/index.php/eot
As an agricultural country, Indonesia has a very diverse range of natural and biological wealth which, if managed properly, can become a mainstay of the national economy. The agro-climatic conditions in Indonesia are very suitable for the development of tropical and some sub-tropical commodities at an altitude between zero and thousands of meters above sea level. Agricultural commodities, including food crops, horticulture, plantation, forestry, animal husbandry, and fisheries with their diversity and uniqueness that are of high value and are reinforced by very diverse cultural wealth, have a strong appeal as agrotourism. Overall, there is a great opportunity to become a mainstay in the Indonesian economy. At present, the view of agriculture seems to be viewed from two different perspectives. Saragih (2001) views the agricultural sector as a business activity (agribusiness), and Mubyarto (1975, 2000) views agricultural sector activities as a way of life of society. It means the agricultural sector must be viewed as business activities and it is still part of the culture of local community life.

Agriculture in any context (including in the context of tourism, in the context of agrotourism development) must still be viewed as part of the community's culture. Furthermore, when talking about culture/ culture as a system, the discussion must include aspects of concept/mindset, social aspects, and aspects of artifacts/materials (Koentjaraningrat, 1993). In this study, there are three main aspects in developing an area as an agrotourism attraction which includes mindset, social, and materiality (Table 1).

\section{Tourism Village Development}

A tourist village is a form of integration between elements of tourist attraction or attractions, accessibility, and structured amenities in the life of local people in an urban area (Lane, 1994a, 1994b; Lane and 
Kastenholz, 2018), a tourist village is included in the rural tourism classification. has a basic concept of empowering the potential of remote areas to increase local people's income (Oppermann, 1996; Balestrieri and Congiu, 2017; Lane and Kastenholz, 2018). A tourism village is a concept associated with low population density in an open space and is associated with small-scale settlements (less than 10,000 inhabitants) (Kiper and Özdemir, 2012). Furthermore, a tourist village becomes an area that has value in attracting tourists to visit through the social and cultural system of the local community (Sanjiwani, 2016; Wijayanti and Sanjiwani, 2019).

In principle, a tourism village is managed by considering five main aspects, including human, material, financial, managerial, and marketing resources (Isdarmanto, 2016). This management is fully carried out by the local community through the concept of community-based tourism. The involvement of the government and the tourism industry is limited to facilitating and motivating local communities as the main actors in the development of tourism villages (Wilson, Fesenmaier, Fesenmaier, \& Van Es, 2001). The main components in developing tourist areas, especially tourist villages, cover three main aspects, namely attractions (tourist attractions), accessibility, and amenities (Table 2) (Buhalis, 2000). An attraction is something that can attract tourists to visit, attractions can be in the form of social and cultural uniqueness, natural beauty, local people's lifestyles to artificial attractions. Accessibility makes it easy for tourists to visit attractions that include facilities and infrastructure. The availability of roads that can be traversed by vehicles safely makes it easier for tourists to move around. Amenities are supporting facilities that aim to support all the needs of tourists.

\section{METHOD}

The approach used in this research is qualitative research with the unit of analy-

Table 1. The main aspect of developing a tourist village

\begin{tabular}{ll}
\hline Aspect & Description \\
\hline Mindset & There is awareness from the local community about the potential they have \\
in the context of developing agrotourism. \\
There are initiatives from outside parties (independent institutions) to en- \\
courage local communities to develop their potential, in the context of the \\
concept of sustainability. \\
There is an agreement with all stakeholders about the vision of agrotourism \\
development in the area. \\
There is an agreement on the proportion of revenue sharing received from \\
agrotourism activities. \\
There is an agreement from the community to make sacrifices for the land \\
they own in the framework of structuring the agrotourism area. \\
Conducting comparative studies to other areas where agro-agricultural ac- \\
tivities are already operational. \\
Tangible \\
Improve infrastructure (roads, shelters for tourists, locations for tourists to \\
enjoy the natural scenery, toilets, etc.). \\
Preparing people's houses as lodging for tourists who want to spend the night. \\
Prepare local people to be able to make souvenirs that are unique to the re- \\
gion.
\end{tabular}

Source : Windia et al. (2007)

http://ojs.unud.ac.id/index.php/eot 
Table 2. As a tourist village area

\begin{tabular}{lll}
\hline Attraction & Accesibility & Amenities \\
\hline a. Natural attraction & a. Air Transportation & a. Tourist services \\
b. Natural events & b. Land Transportation & b. Accomodation \\
c. Built attraction & c. Sea Transportation & c. F\&B service \\
d. Built event & & d. Public service \\
\hline
\end{tabular}

Source : Buhalis (2000)

sis, namely the elements or aspects of developing agro-tourism attractions, while the unit of analysis in the development of tourist villages includes attractions, accessibility, and amenities. Primary data collection techniques were carried out through semi-structured interviews with interview guides with relevant stakeholders including government agencies in charge of tourism and community institutions in Sukalarang Village by personal communication. Through this interview, primary data was obtained in the form of analysis of social aspects, aspects of mindset and tangible aspects. Meanwhile, secondary data collection in the form of information was carried out using a desk study and aimed to obtain data and information from various policy documents, libraries, and previous research on the attractiveness of agro-tourism and tourist villages. This study uses qualitative descriptive analysis and content analysis methods.

\section{RESULTS AND DISCUSSION}

Referring to the research concept of three main aspects of agrotourism attractiveness, it can be identified that the development of agrotourism attractiveness in Sukalarang Village includes mindset, social, and materiality. The findings in Table 3-5 were analyzed based on the existing conditions in Sukalarang Village.

In the mindset aspect of developing agrotourism attraction in Sukalarang Village, it can be identified that there is no awareness of the local community to make the area a tourist village with its main attraction, namely agrotourism. Furthermore, there is no initiative from the relevant stakeholders (local communities, plantation owners, and the Sukalarang Village/ Sukabumi District Government) to make Sukalarang Village an Agrotourism village. Briefly, the analysis of aspects of the mindset can be seen in Table 3.

On the social aspect, it can be iden-

Table 3. Aspects of the mindset of developing agrotourism attraction

\begin{tabular}{|c|c|}
\hline Aspects of the mindset & Analyze \\
\hline $\begin{array}{l}\text { There is awareness from the local community } \\
\text { about the potential that is owned in the frame- } \\
\text { work of developing agrotourism. } \\
\text { There are initiatives from outside parties (inde- } \\
\text { pendent institutions) to encourage local com- } \\
\text { munities to develop their potential, in the con- } \\
\text { text of the concept of sustainability. } \\
\text { There is an agreement with all stakeholders re- } \\
\text { garding the vision of developing agrotourism } \\
\text { in the area. }\end{array}$ & $\begin{array}{l}\text { The local community does not yet know about } \\
\text { Sukalarang Village as an agrotourism attrac- } \\
\text { tion. } \\
\text { There is no initiative from outside to develop } \\
\text { agrotourism potential in Sukalarang Village. } \\
\text { There is no agreement between the local com- } \\
\text { munity, plantation landowners, and the gov- } \\
\text { ernment of Sukalarang Village/ Sukabumi Re- } \\
\text { gency to develop agrotourism attraction. }\end{array}$ \\
\hline
\end{tabular}


tified that the preparedness of the local community has not been fully focused on agrotourism. So far, local people have been carrying out their activities only to fulfill their daily needs with their activities in the garden (Figure 1). The land is fully owned by individuals who are not from Sukalarang Village, while the land owned by the local community is designated for parking and accessibility facilities. Furthermore, there has been no effort to make a comparative study to an area where agrotourism attractiveness has developed. Briefly, the analysis of aspects of the mindset can be seen in Table 4.

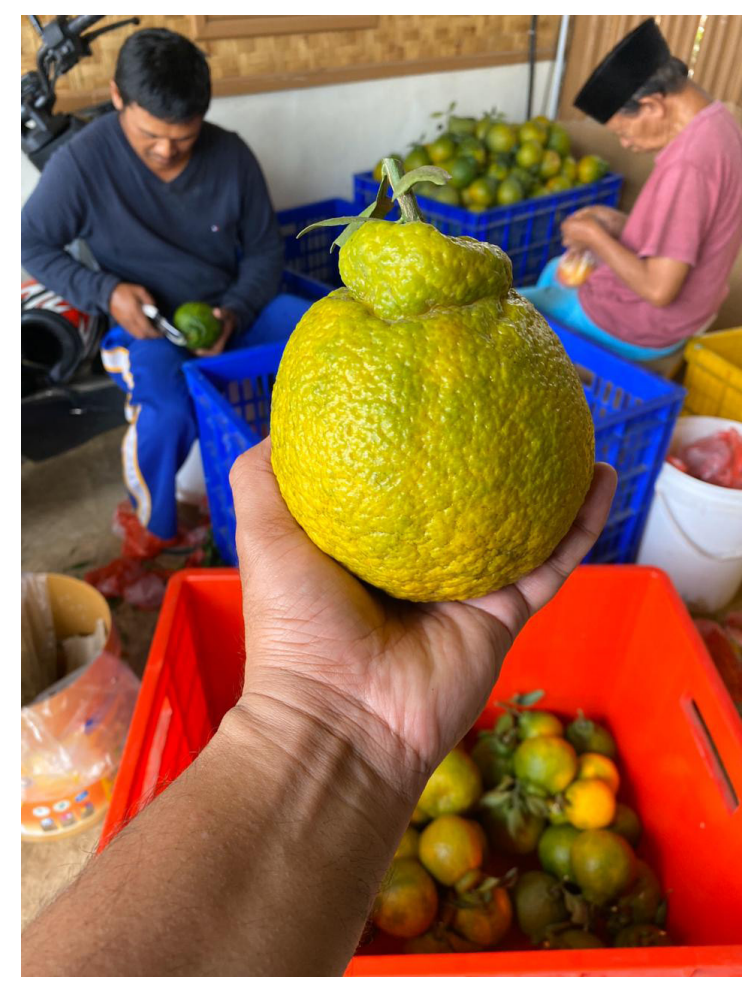

Figure 1. Local community activities in the Sukalarang Citrus plantation

Based on material aspects, the condition of the infrastructure, namely the road to Sukalarang Village, is very adequate with regular repairs (Figure 2). The absence of lodging facilities provided by the local community is one of the things that need to be improved. Furthermore, Sukalarang Orange is one of the icons of Sukalarang
Village and is currently used as a typical souvenir of Sukalarang Village (Figure 3). Briefly, the analysis of aspects of the mindset can be seen in Table 5 .

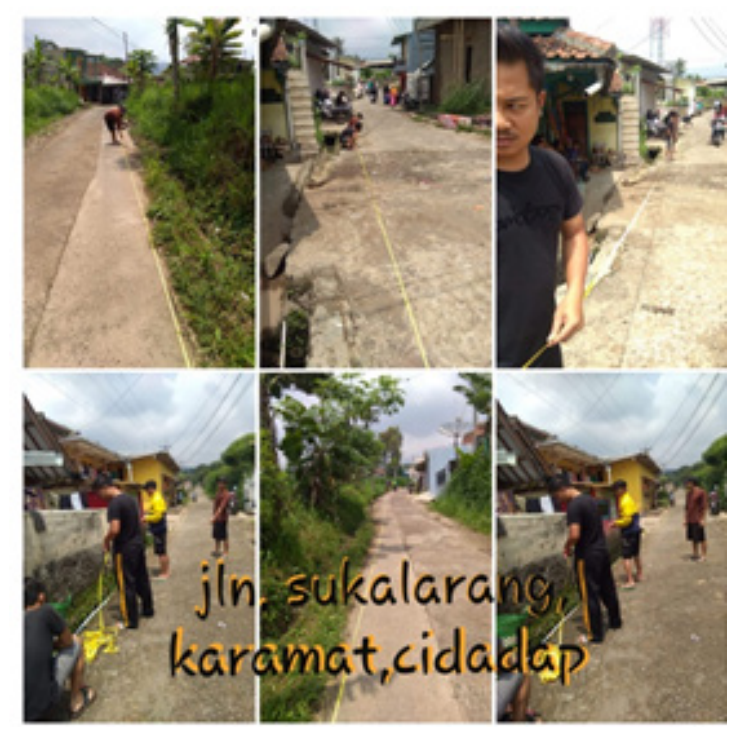

Figure 2. Conditions of accessibility to the Sukalarang Citrus plantation

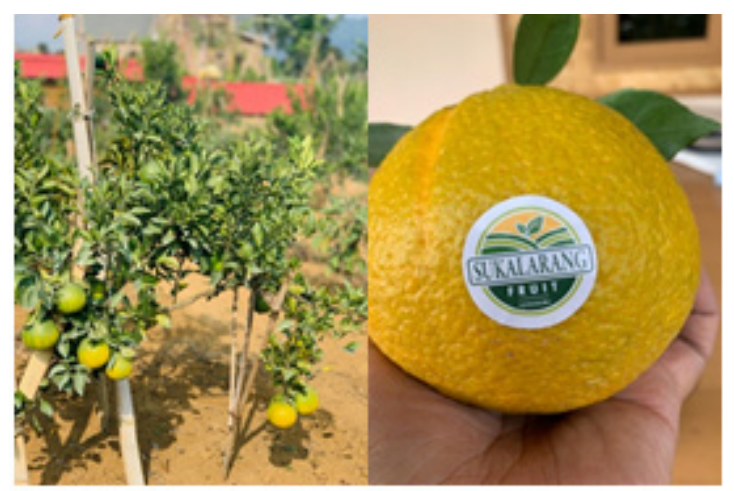

Figure 3. Sukalarang Orange has become an icon of the present village

\section{CONCLUSION}

The existing conditions of the community in Sukalarang Village still make agricultural and plantation activities their daily activities. Agrotourism which can be a mainstay of Sukalarang Village is not well understood by the local community. It takes initiation from the plantation owners and the government of Sukalarang Village and Sukabumi District to make Sukalarang 
Table 4. Social aspects of the development of agrotourism attraction

\begin{tabular}{lll}
\hline \multicolumn{1}{c}{ Social Aspect } & \multicolumn{1}{c}{ Analyze } \\
\hline $\begin{array}{l}\text { 1. There is an agreement on the proportion of revenue } \\
\text { sharing received from agrotourism activities. }\end{array}$ & $\begin{array}{l}\text { 1. The existing condition of the distribution of income } \\
\text { received from activities only comes from agricultural } \\
\text { activities. }\end{array}$ \\
$\begin{array}{ll}\text { 2. There is an agreement from the community to make } \\
\text { sacrifices for the land they own in the framework of } \\
\text { structuring the agrotourism area. }\end{array}$ & $\begin{array}{l}\text { 2. There are several lands owned by residents only for } \\
\text { parking facilities for visitors. Meanwhile, plantation } \\
\text { land is only owned by individuals outside the local } \\
\text { 3. Conducting comparative studies to other areas where } \\
\text { agricultural activities are already operational. }\end{array}$ \\
$\begin{array}{ll}\text { commity. } \\
\text { cal community on the attractiveness of agrotourism } \\
\text { in West Java. }\end{array}$ \\
\hline
\end{tabular}

Table 5. Material aspects of developing agrotourism attraction

\begin{tabular}{|c|c|}
\hline Tangible Aspect & Analyze \\
\hline $\begin{array}{l}\text { 1. Improve infrastructure (roads, shelters for tourists, lo- } \\
\text { cations for tourists to enjoy the natural scenery, toilets, } \\
\text { etc.). }\end{array}$ & $\begin{array}{l}\text { 1. The condition of the road to the agrotourism attraction } \\
\text { of Sukalarang Village is adequate and there are efforts } \\
\text { to improve the road conditions that are not good. }\end{array}$ \\
\hline $\begin{array}{l}\text { 2. Preparing people's houses as lodging for tourists who } \\
\text { want to spend the night. }\end{array}$ & $\begin{array}{l}\text { 2. There has been no attempt to make residents' houses } \\
\text { lodging places. }\end{array}$ \\
\hline $\begin{array}{l}\text { 3. Prepare local people to be able to make souvenirs that } \\
\text { are unique to the region. }\end{array}$ & $\begin{array}{l}\text { 3. There is no identity for Sukalarang Village through } \\
\text { making souvenirs. Only the identity of Jeruk Sukala- } \\
\text { rang as an icon of Sukalarang Village. }\end{array}$ \\
\hline
\end{tabular}

Village an agrotourism village. This is indicated by the potential for citrus plantations. Furthermore, there is one icon that can support Sukalarang Village as an agrotourism village, namely Jeruk Sukalarang.

\section{REFERENCES}

Balestrieri, M. and Congiu, T. (2017) 'Rediscovering rural territories by means of religious route planning', Sustainability, 9(3), p. 363.

Brščić, K. (2006) 'The impact of agrotourism on agricultural production', Journal of Central European Agriculture, 7(3), pp. 559-563.

Buhalis, D. (2000) 'Marketing the competitive destination of the future', Tourism management, 21(1), pp. 97-116.

Departemen Pertanian (2003) Direktori Profil Agrowisata: Agrowisata Meningkatkan Pendapatan Petani.

http://ojs.unud.ac.id/index.php/eot

Herrera, A. C. and Magdalena, L. (2004) 'Agriculture, Environmental Services and Agro-Tourism in the Dominican Replubic. eJADE', electronic Journal of Agricultural and Development Economics, 1(1), pp. 87-116.

Kiper, T. and Özdemir, G. (2012) 'Tourism Planning in Rural Areas and Organization Possibilities', in Landscape Planning. Intechopen.

Koentjaraningrat (1993) Kebudayaan, mentalitas, dan pembangunan. Jakarta: Gramedia Pustaka Utama.

Lane, B. (1994a) 'Sustainable rural tourism strategies: A tool for development and conservation', Journal of Sustainable Tourism, 2(1-2), pp. 102-111. doi: $10.1080 / 09669589409510687$.

Lane, B. (1994b) 'What is rural tourism?', Journal of sustainable tourism, 2(12), pp. 7-21.

Lane, B. and Kastenholz, E. (2018) Rural 
tourism: new concepts, new research, new practice. Routledge.

López, E. P. and García, F. C. (2006) ‘Agrotourism, sustainable tourism and ultraperipheral areas: The case of Canary Islands', PASOS Revista de turismo y patrimonio cultural, 4(1), pp. 85-97.

Mubyarto (1975) Pengantar Ekonomi Pertanian. Jakarta: LP3ES.

Mubyarto (2000) 'Ceramah yang disampaikan dalam HUT Koperasi UGM tahun 2000 di Yogyakarta'.

Nuryanti, W. (1993) 'Concept, Perspective and Challenges, makalah bagian dari Laporan Konferensi Internasional mengenai Pariwisata Budaya', Yogyakarta: Gadjah Mada University Press. Hal, pp. 2-3.

Oppermann, M. (1996) 'Rural tourism in southern Germany', Annals of tourism research, 23(1), pp. 86-102.

Sanjiwani, P. (2016) 'Kebijakan Pemerintah Terhadap Kelembagaan Kelompok Sadar Wisata (POKDARWIS) dalam Pengembangan Desa Wisata di Provinsi Bali.', Paradigma dan Kebijakan Pariwisata, 1(13).

Saragih, B. (2001) 'Paradigma Baru Pembangunan Ekonomi Berbasis Pertanian', PT Loji Griya Sarana. Bogor.

Wijayanti, I. G. and Sanjiwani, P. K. (2019) 'Pengelolaan Desa Wisata KabaKaba, Kecamatan Kediri, Kabupaten Tabanan: Suatu Analisis Kualitatif', Jurnal Destinasi Pariwisata, 7(2), pp. 344-351.

Windia, W. et al. (2007) 'Model Pengembangan Agrowisata di Bali', SOCA: Jurnal Sosial Ekonomi Pertanian, 7(1), p. 43979. 